\title{
Sober masculinity and nurturing femininity: a gendered analysis of the Syrian presidency Instagram account
}

\author{
Andrea Stanton $^{1}$ (D) \\ Revised: 1 December 2021 / Accepted: 8 December 2021 / Published online: 24 January 2022 \\ (c) The Author(s), under exclusive licence to Springer Nature Limited 2021
}

\begin{abstract}
Since July 2013, Syrianpresidency, the "official Instagram account for the Presidency of the Syrian Arab Republic" has featured a high percentage of photos of President Bashar al-Assad and of his wife, Asma. This article takes Syrianpresidency as an important aspect of the Assad government's digital public diplomacy, because of its strong visuality. Using case study and content analysis approaches, it surveys a sample of Instagram posts from January 2016, when the Syrian military began retaking territory from ISIS, through March 2020, covering Syria's initial response to the COVID-19 pandemic. It argues that Syrianpresidency frames the Assads for a regional and international audience through the lens of a 'gendered modernity,' portraying them as companionate spouses serving Syrians in complementary ways. Syrianpresidency aims its public diplomacy at domestic and foreign audiences, working to project a positive image as part of its efforts to manage and ultimately end the Syria conflict. In doing so, it engages in an updated form of what Wedeen terms 'as-if' politics and a politics of erasure, effacing the regime's violence and citizen resistance through silence.
\end{abstract}

Keywords Syria $\cdot$ Instagram $\cdot$ Gender $\cdot$ Digital diplomacy $\cdot$ Middle East $\cdot$ Politics of erasure

\section{Introduction}

On July 24, 2013, Syrianpresidency, described in English as the "official Instagram account for the Presidency of the Syrian Arab Republic", debuted on Instagram, posting 62 separate photos, one after the next. The photos were dated from 2011 to 2013; some had no captions, some only gave the date, and some gave brief descriptions of the circumstances-President Bashar al-Assad drinking coffee with Syrian workers to celebrate Labor Day, or meeting a delegation from the Iranian Parliament. The captions were written entirely in Arabic. The hashtags below each caption were bilingual, with hashtags appearing first in Arabic and then in English. Of these 62 first-day posts, 35 featured Bashar, mostly in the company of other Syrians-giving speeches, shaking hands with religious and other dignitaries, visiting wounded soldiers in the hospital, and interacting with ordinary citizens; 20 featured First Lady Asma al-Assad, mostly in the company of Syrian students, mothers, and/or children

Andrea Stanton

Andrea.stanton@du.edu

1 University of Denver, Denver, USA with disabilities; and four photos featured the two together, visiting the children of soldiers killed in the civil war and volunteering in a community support initiative. The photos drew between 250 and 500 likes, with the last one- of Assad at his desk, looking through papers-drawing nearly 900 . They also drew comments-some supportive, some critical-ranging from fewer than 10 on many photos to nearly 350 on one of Assad receiving a plaque of iconic Turkish president Kemal Ataturk.

While Syrianpresidency later established a more regular posting rhythm, its focus on Bashar al-Assad and Asma alAssad remained - and its number of followers and average number of likes steadily increased. Launched in a moment of crisis for the Assad government, it has developed into a robust platform for the regime's digital public diplomacy. This article analyzes Syrianpresidency as a central instantiation of the Assad government's digital public diplomacy. It moves past the account's early, experimental period, focusing on a 5-year period from 2016-2020. It starts in January 2016, as the Syrian military began retaking territory from ISIS and other opposition groups, relying heavily on Russian military support-and just after having retaken the key opposition city of Hama in December 2015. It continues through March 2020, covering the government's 
early response to the COVID-19 pandemic. It finds that the account operates at three levels: first, it works to harness citizen acquiescence through an updated version of what Lisa Wedeen termed 'acting as-if' politics. Second, it attempts to efface opposition to the Assad government and expunge violence by the government through a politics of erasure. Third, it builds on the first two by trying to persuade regional and international audiences of the Assads' respectability through gendered displays of modernity.

\section{Public diplomacy and the Syrian context}

This analysis takes an approach informed by two lenses: that of digital public diplomacy, and that of domestic public diplomacy. Both are currently minor but growing approaches within the broader public diplomacy field, as they reflect states' and governments' needs to connect with and convince their own populations, and to do so via digital methods and platforms. Public diplomacy has been broadly understood as an effort to influence the views of foreign publics. However, Syria's extended conflict and the state of civil war that has prevailed across much of the country since 2011 blur and call into question simple distinctions between "domestic" and "foreign." The civil war context, this analysis asserts, means that the Syrian public incorporates a number of subpublics, from those that consider themselves part of the traditional national public, endorsing the Assad government as the sole legitimate authority over Syria, along a continuum of publics with decreasing allegiance to that government and the version of Syria it claims-ending with increasingly hostile sub-publics, some of whom consider themselves Syrian and the Assad government illegitimate and alien to Syria, and others who consider national identity itself illegitimate. Some of these sub-publics have parallel communities outside Syria - in neighboring Arab countries, in Europe, and in North America. Syrianpresidency's posts cross these two sets of blurred lines, addressing supportive and nearsupportive sub-publics of Syrians in Syria, supportive and near-supportive sub-publics of Syrians outside Syria, and other Arabic speakers in the region and beyond.

The images and texts of Syrianpresidency's Instagram posts do so by highlighting the roles and personas of Bashar and Asma al-Assad as respectable participants in a Euronormative, global modernity, gendered in distinct but complementary ways that fit within a Syrian context. They echo and update colonial-era efforts to 'measure' and evaluate colonized societies based on their relative conformance to particular European gender relations and gendered activity norms. These pressures sparked lively internal debates among men and women in colonized societies, connecting with existing conceptions of gendered relations and indigenous traditions of social reform. In the Middle East, these pressures also frequently generated reconfigured notions of modernity, in which distinct and complementary roles for men and for women (Abu-Lughod 1998; Clancy-Smith and Gouda 1998) played an important role in determining the contours of acceptable, authentic forms of modernity. These understandings of Middle Eastern modernity also increasingly emphasized the merits of companionate marriage: one in which husband and wife developed a lasting affection, based on intellectual, moral, and patriotic sensibilities, and served as anchors of the nuclear family that they established (Motlagh 2012). Hence, this article uses the term "gendered modernity" to reference the forms of modernity articulated starting in the late 1800s, for which particular concepts and practices of genderedness have been instrumental.

Syrianpresidency coalesces its contemporary iterations of these earlier depictions of gendered modernity around two axes. First, that of Bashar al-Assad's 'sober masculinity,' characterized by hard work, concern for those under his charge, and steadfastness in dealing with domestic and foreign policy issues. Second, that of Asma al-Assad's 'nurturing femininity,' characterized by empathy, concern for the vulnerable, and a focus on the domestic or national sphere. These two portrayals locate the Assads' positionalities as normatively gendered masculine and feminine, in ways that recast the ascetic, military masculinity of Hafez al-Assad and the near-invisibility of Anisa Makhlouf, Bashar alAssad's parents. This recasting is presented as an evolutionary shift, but not a critique, that better reflects contemporary Syria. These portrayals also present the Assads as implicit foils to ISIS and other extremist or fundamentalist opposition groups: a non-militant Muslim man, a non-oppressed Muslim woman; and especially Bashar al-Assad as neither a hyper-masculine, militaristic despot nor a feminized, decadent monarch. In this context, it is helpful to recall Butler's argument that gender is discursively and performatively created and solidified, rather than pre-existent or innate (Butler 1999). The Assads engage in performances of masculine and feminine genders that locate themselves within Euronormative gender while also presenting these genders as normative in a Syrian context.

\section{Public diplomacy and the digital context}

Since its debut as an Apple iOS app in October 2010, Instagram has become the dominant photo (and video) social media platform, operating in over 30 languages by mid2021. While often short-handed as a photo-sharing app, Leaver et al. argue that it is best described as "a conduit for communication in the increasingly vast landscape of visual social media cultures." The visual elements-photos and videos-are critical to Instagram users' storytelling, but their ultimate purpose is communication. Photos and videos combine with captions, hashtags, account information, and other users' comments to produce communicative meaning 
for account followers. While many Instagram users are ordinary individuals, some are "influencers", and some are corporations or other institutions - and, increasingly, some are politicians or other political entities. "Politicians across the globe are turning to Instagram to engage with their citizens, sharing their thoughts and lives", particularly in democratic contexts (Leaver et al. 2020). The Syrianpresidency account offers a seemingly less-common example of a major politician account in an autocratic political context.

Scholars of public diplomacy have recognized the importance of digital platforms, including older online media forms like websites and more contemporary platforms like Twitter. Some, like Duncombe, argue that mobilizing audience emotions around particular identities is key to successful public diplomacy efforts on social media platforms (Duncombe 2019). While digital diplomacy studies have tended to focus on Facebook or Twitter campaigns, scholars increasingly recognize that Instagram is used for digital public diplomacy. Manor cites Instagram's imageand caption-based platform as leading the "transition toward narrative-based public diplomacy", some with targeted and others with tailored communications. Targeting, Manor argues, involves crafting broad messages that appeal to large audiences. Tailoring, by contrast, involves crafting particular messages that resonate with particular audiences, requiring knowledge of their values, worldview, and culture as well as particular platforms or media channels they frequent. For him, the key takeaway is that diplomatic institutions and the work of public diplomacy have all been impacted, and will continue to be impacted, by digital technologies (Manor 2019).

This analysis follows recent scholarship that argues for considering domestic public diplomacy as a subset of public diplomacy as a way of capturing the complexity of the Assad government's public diplomacy efforts, including the genderedness of these efforts. In this digital media environment and with these overlapping publics and sub-publics, foreign-focused public diplomacy and domestic-focused public political communication efforts may overlap and intersect both in their messaging and in the audiences they reach. As Huijgh notes, this development is global and not unique to Syria: "social media and the increasing mobility of global citizens have blurred distinctions between domestic and international audiences" (Huijgh 2013). Yet discussions of the domestic turn for public diplomacy have also invoked ideas of collaborative, multi-vocal and multi-directional communication - between domestic and foreign civil actors, for example, with the state playing a mere "facilitative role" (Pisarska 2016). Instagram is by its nature a bi-directional platform, but followers can merely comment on posts rather than engaging in a full dialogue-making the relationship between account and followers more like call and response than collaboration. Further, blocking unwanted followers is easy-meaning that Syrianpresidency and other accounts can curate their followers to silence critics, allowing them to use Instagram like a propaganda outlet. Consequently, this article engages with scholarship on domestic public diplomacy while noting that the blurring of domestic and foreign audiences evidenced in Syrianpresidency's posts and responses can further government-controlled social media outlets' efforts at propagandistic public diplomacy efforts, as discussed in more detail below. In this process, gendering and genderedness plays a foundational but subtle role.

\section{Historical and political background}

Bashar al-Assad came to power in 2000, following the death of his father, Hafez al-Assad. The senior al-Assad had come to power in 1971, nearly a decade after the Ba athist revolution that ended multi-party democracy in Syria, in favor of a secular, Arab nationalist, anti-colonial, socialist-leaning state. Under Hafez al-Assad, the state promoted national advancement through land reform, import substitution industrialization, mass education, and the promotion of a middleclass lifestyle for all. It also promoted an extensive cult of the leader, focused on Assad and later on his son; and maintained control over Syrian citizens through a deeply repressive state police system, known in Arabic as the mukhabarat (van Dam 2011).

Hafez al-Assad planned for his oldest son Bassel to succeed him, but shifted focus to Bashar after Bassel died in a car accident in 1994. Bashar al-Assad trained as an ophthalmologist and was known for heading the Syrian Computer Society, which together gave him a reputation as a modernizer and reformer. Assad's image as a reformer shifted after the assassination of former Lebanese prime minister Rafik al-Hariri in 2005-which was popularly blamed on Hezbollah and the Syrian government - and after the death, imprisonment, or exile of his father's key advisors, who had retained positions in the government after Hafez al-Assad's death. Bashar al-Assad's economic liberalization program exposed major wealth gaps among Syrians, while the introduction of the Internet and new media platforms exposed Syrians to a broader variety of views. As in many parts of the world, Syria saw increasing religiosity throughout its population, and particularly among Sunni Muslims; as sectarianism increased around the region, Assad's religious identity as an 'Alawi, a member of an offshoot of Shiite Islam, became a more contentious issue for some (van Dam 2011; Khatib 2011).

Yet when the Arab Spring began rippling across the region, beginning with Tunisia in December 2010, few in Syria or outside believed that it would impact Syria. When protests began in March 2011, they appeared to take the Assad government by surprise. However, it soon responded with violence, escalating rather than stifling the opposition. 
By Summer 2011, peaceful protests began giving way to militarized opposition, leading to the outbreak of the conflict and de facto civil war. While the Assad government received financial, weapons, and military support from Iran, Hezbollah, and later Russia, it struggled (al-Haj Saleh 2017).

Syrianpresidency's 2013 launch came during a moment of crisis, as the Assad government struggled to maintain control within Syria and manage negative domestic, regional, and international narratives about its role in the Syrian civil war. After 2 years of militarized conflict, government forces continued to lose territory, despite support from Iran, Hezbollah, and Russia (Kozak 2015). Opposition came from a broad mix of Syrian citizens, aligned with various resistance groups-some organized along ethnic lines, like the Kurdish militias, some along sectarian or religious lines, like Jabhat al-Nusra, and some along Syrian national lines, like the coalition of groups in the Syrian National Council (Rafizadeh 2012).

In this critical moment, the Assad government shifted its communications strategy. Historically, the Assad government relied on press releases and articles from the Syrian Arab News Agency (SANA) - a print-based agency, founded in 1965, that operated primarily in Arabic. In 2013, the government rapidly embraced a suite of social media platforms-as well as an overhauled SANA website. In Spring 2013, official Assad government accounts launched on Facebook, Twitter and YouTube, with the Instagram account added in July. (A Syrianpresidency Telegram account was added in October 2015.) Initially, the social media efforts were erratic and attracted relatively few followers or likes. They appeared deliberately consistent: the same images and videos frequently appeared on multiple platforms, with the same or similar captions, although modified as appropriate: the YouTube account would only include videos, for example (Holiday et al. 2015).

While the Instagram account was not the first to appear, it appears particularly significant due to its focus on images. As Neumann and others have argued, "visual diplomacy" plays an important role in public diplomacy efforts, although much public diplomacy scholarship focuses on textual interventions (Neumann 2020). It also offers two simple means of determining audience impact: the number of account followers and the number of likes on particular posts. Unlike Facebook, which allows users to respond to posts with a range of emotions (likes, loves, dislikes, anger, etc.) and YouTube, which allows users to respond to videos with a "thumbs up" or "thumbs down", Instagram and Twitter only permit likes. (All these platforms also allow comments, but far fewer viewers/page visitors respond to posts with written comments.) Scholars examining the psychological effects of Instagram have noted that the lack of negative response buttons reinforces or inflates perceptions that users endorse particular posts-or accounts. As Caldeira notes:
"As Instagram, like many other social networks, does not possess a "dislike" button, the images [posted] can only be judged by the amount of "likes" they possess, instead of by a more accurate proportion of "likes" and "dislikes"" (Caldeira 2016). For this study, focusing on a visually rich online platform that attracts viewers while constraining the scope of their responses helps provide a useful case study for analyzing Assad government digital diplomacy with respect to the gendered portrayals (or performances) of Bashar and Asma al-Assad.

\section{Approach and findings}

\section{Methodology}

Existing scholarship on Instagram has tended to focus on user behavior-for example, overall user motivations (Lee et al. 2015)—, its role as a large-scale data source-for example, in urban studies (Boy and Uitermark 2016)—, or case studies around a specific topic or theme-for example, professional athletes' self-presentation (Smith and Sanderson 2015). This article employs a case study approach, but examines only one Instagram account: the official account of the Syrian presidency. Its central work included visual and textual content analysis of five sample sets, which consisted of all Syrianpresidency posts from January 1 through March 31 in 2016, 2017, 2018, 2019, and 2020, using inductive reasoning to derive analytic conclusions from the data studied. After experimenting with several "scraping" or data mining tools, the researcher reverted to manually collecting and noting the data and details of each Syrianpresidency Instagram post for the periods covered in this study. Manual data entry allowed for more robust descriptions of the image(s) associated with each post and permitted co-locating all hashtags for a post in the same cell, as well as reducing possible errors in word positioning when posts included both left-to-right and right-to-left scripts.

Manual data entry and analysis was feasible due primarily to the relatively small amount of data in each sample set. The number of posts in each set ranged from 24 in 2017 to 53 in 2016. Data captured included each post's date, image description, people in them, the caption as translated into English, the hashtags, and the number of likes (or, for videos, the number of views). Of course, the bulk of this information was similarly captured by the scraper / data mining tools considered for this project, but, as noted above, they tended to have minimal image descriptions, to separate hashtags individually, and to have some challenges with the dual-script nature of Syrianpresidency's posts. The posts in each data set were categorized according to the central people appearing in the image(s) included in the post, and then each post was analyzed in accordance with the image 
Syrianpresidency: Categorized Posts Jan-March, 2016-2020

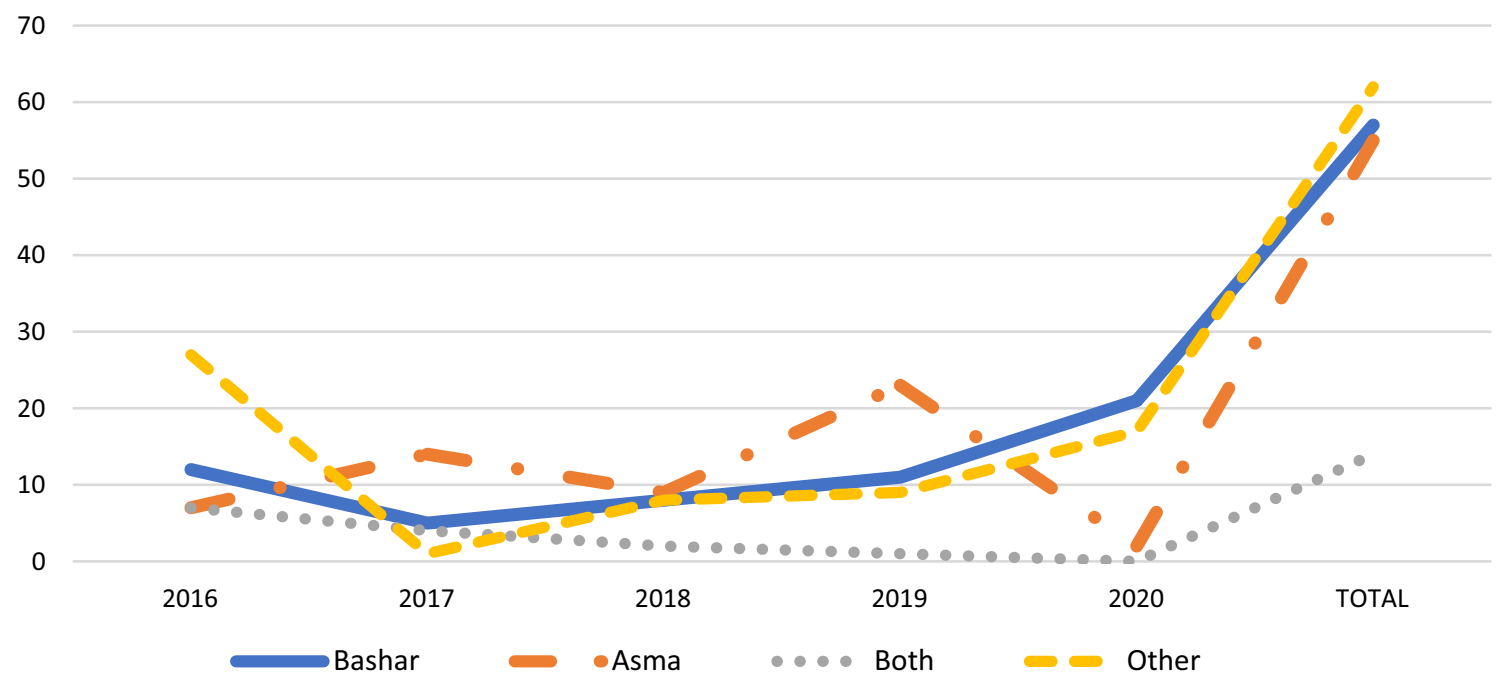

Fig. 1 Syrianpresidency Instagram posts from January through March, 2016-2020, categorized according to whether they focus on Bashar alAssad, Asma al-Assad, both, or some other subject

description, caption, and hashtags to identify key characteristics - which were in turn used to identify the key themes that underpin the account's public diplomacy work.

\section{Findings}

As with the range in the total number of posts each year, the data suggest some variation in the relative number of Bashar-, Asma-, both-, and other-focused posts from year to year, while also showing clear trends for the period under study. Syrianpresidency posted an average number of 38 times in the first 3 months of the year from 2016 to 2020 , ranging from a low of 24 posts in 2017 to a high of 53 in 2019. 30 percent of these focused on President Bashar alAssad and 29 percent focused on Asma al-Assad. 33 percent focused on something other than the Assads, although this high distribution reflects an outlying number of "other" posts for International Women's Day in 2016. ("Other" posts are a bit of a catch-all category, but broadly address themes of defense, patriotism, and sacrifice, within images and captions praising the Syrian soldier, the Golan Heights, Syrian women, or Presidential decrees.) Seven percent focused on the two Assads together, generally while also engaging with particular Syrian citizen constituencies: wounded soldiers and their families, teachers, etc. While offering a helpful dataset in the aggregate, these numbers and percentages varied considerably from year to year. For example, in 2019, there were 23 Asma-focused posts and only nine Basharfocused posts, while in 2020 there were 21 Bashar-focused posts and only two Asma-focused posts.
This variation points to the account's evolving approach. All the 2016 posts were single-photo posts, although the account sometimes posted multiple times in one day, and often on the same subject or event. The same was true of Syrianpresidency's 2017 posts, although Instagram enabled users to post up to 10 photos in one post starting in February 2017. In 2018, 23 of the 27 posts were single-photo posts, but there were a few posts with multiple photos-including one ten-photo post of Asma al-Assad hosting women soldiers and their mothers at the Presidential Palace, as a Mother's Day celebration. Single-photo posts continued to be the norm in 2019 and 2020, but multiple-photo posts made up 20-48 percent of the posts in those years. Posts in these years also included a small number of video posts, a posting option that Instagram had introduced in 2013. But overall, across the 5-year span, over 80 percent of the total posts included single photos, suggesting Syrianpresidency's distinct preference for this approach over multiple-photo or video posts (Fig. 1).

The use of language in these posts alludes to the intended audiences. From August 2013 through mid 2014, the account shifted between Arabic- and English-language captions, as well as some that posted Arabic captions with English translations below. Since then, it has provided captions in Arabic, with hashtags embedded in the captions, and with English-language hashtags below the captions. While some captions are brief - three to seven words noting an event or holiday — many are lengthy, with quotes from current or past speeches by Bashar or Asma al-Assad. Without being able to read and understand these captions, the photos used for each post would often be relatively difficult for account followers 
to decipher: another photograph of Bashar speaking from a podium, or of Asma sitting with citizens. The captions suggest that the account intends to reach an Arabic-fluent and fully literate set of publics-including Syrians as well as regional audiences.

Yet the hashtags suggest a slightly different set of imagined publics and digital engagements. The Arabic-language hashtags tend to be embedded in the captions and primarily used for place names - cities, governorates, countries-and for the names of major political figures, like the Assads, Russian President Vladimir Putin, and similar. They also often highlight key events or initiatives, like the Wounded Soldier project or the Syrian Science Olympiad-which may be important to propose as hashtags to the account's intended audience, but which are too specific to gain much traction on Instagram. The English-language hashtags tend to be a mixture, with some Syria-specific terms and place names, like \#Assad, \#SyrianArmy, or \#Palmyra, and some general words that often evoke particular values, like \#Brave, \#Hero, or \#Love. Some seem intended to connect with broader Instagram user practices, as with \#PhotoOfTheDay and \#BestOfTheDay. Others make more pointed arguments about the Assad government's view of the Syria conflict, like \#Terrorists, \#Torture, and \#Kidnapped-words Syrianpresidency used in early 2017 to describe the government's retaking of territory near Latakia from rebel forces, calling them terrorists who kidnapped or made hostages of the local populations. Others highlight the names of foreign leaders and countries sympathetic to the Assad government, like \#Putin, \#Iran, and \#UAE-or of international organizations and media outlets whose representatives have met with Bashar al-Assad, like \#ICRC or \#AFP. Together, the Arabic-language hashtags seem more closely integrated into the caption and the post's main message, while the Englishlanguage hashtags appear as stand-alone terms, with less to connect them to the specific context of the photo and the Arabic caption.

\section{Posts depicting Bashar al-Assad}

Bashar al-Assad had been president for over a decade when the Syria conflict began and for nearly 16 years at the starting point for this analysis. His portrayals in Syrianpresidency's photos and posts show him in contexts and positions that were not new for him, and exhibit themes that continued elements of his public presentation that predated the Syria conflict. This analysis looks at three of them, tracing their evolution and relative prominence over the 4-year period surveyed: domestic policy, military engagement, and foreign relations. (A fourth category, presidential decrees and other laws, is discussed briefly in the "Findings" section.) These themes emphasize al-Assad as a figure of sober and caring masculinity, making reasoned decisions for the good of the
Syrian nation, commanding the military as a civilian leader, and marking holidays that reflect and celebrate the country's religious diversity.

While Syrianpresidency focuses on Bashar al-Assad as Syria's president, it is notable that the name of the account focuses on the institution rather than on the figure of the president. That focus elides the distinction between Assad and the presidency, fitting a state in which the office of president is generally a lifetime position. As noted above, posts focused on Bashar al-Assad do not dominate Syrianpresidency; only 30 percent of the posts in the period surveyed focus on him. From a follower's perspective, then, Syrianpresidency encompasses the president, his wife, and the various posts in the "other" category as collectively embodying the presidency, with distinct but related roles to play.

The majority of the posts focused on Bashar al-Assad portray his engagement with Syrians and with domestic governance issues, with many photos showing him interacting with Syrian citizens and some that show him alone-working in his office, speaking at a podium, or similar. For example, a February 2016 post shows him smiling and looking slightly off-camera, wearing a suit and tie, and with the Syrian flag behind him. The caption includes a 2012 statement from him that "Throughout history, we have \#triumphed over all the haters" and citing Syria's citizens, institutions, and military as factors in the government's anticipated victory. ${ }^{1}$ Other posts show him talking with or embracing Syrians who had suffered due to the conflict: embracing women and children from the "kidnapped" populations of the Latakia countryside in February 2017, for example, while praising them for their "steadfastness" and describing Syrians as "standing together" with this community as they recovered. ${ }^{2} \mathrm{He}$ also appears before other government institutions-speaking to the heads of city or town councils in February 2019, for example. ${ }^{3}$ Whether speaking from a podium, seated at his desk, standing in a group of soldiers or bending down to listen to a child, Assad appears hard-working, deeply involved in the lives of Syrian citizens, and committed to their welfare-a sober, caring president who acts as a paternal, fraternal, and filial figure as appropriate.

A number of Bashar-focused posts show him interacting with soldiers and the military, as with a series of posts

\footnotetext{
${ }^{1}$ Syrian Presidency (@Syrianpresidency). 2016. "Qala al-Assad ...." Instagram post. 2.3.2016. Interestingly, the caption for this post includes one of the few mentions of God found in this study.

2 Syrian Presidency (@Syrianpresidency). 2017. “Khilal istiqbala lahum al-yom ..." and "Nahna bil-akheer kilna rah nakoun ...." Instagram posts. 2.9.2017. The Arabic caption here includes spoken Syrian Arabic for Bashar's quotes, with formal Arabic for the wrapping text.

3 Syrian Presidency (@Syrianpresidency). 2019. “a-Ra'is \#al-Assad fi kalimatihi al-yom ....” Instagram post. 2.17.2019.
} 
from March 18, 2018. The posts celebrate the Syrian army's recapture of Ghouta, an area outside Damascus, and show him in clusters of soldiers, talking and listening. They also show him interacting with Ghoutawi citizens, newly "freed" by the Syrian army. The captions are brief but highlight the presence of soldiers and officers. ${ }^{4}$ These posts, showing Bashar al-Assad with members of the military, are amplified by the posts of individual soldiers in the "other" category-suggesting that the military is an integral part of the Syrian presidency. They do not, however, suggest that Assad is a military figure. While some Syrianpresidency posts include photos of a younger Bashar al-Assad during his military service, the contemporary photos show him in civilian garb - in the 2018 photos, a suit and dress shirt, but no tie-reinforcing the idea of the presidency as separate from, but honoring, the military as a national institution.

Relatively few posts address foreign policy or directly reference other states-with the exception of a small number of meetings with supportive heads of state, like Russia's Vladimir Putin and other Russian military and political officials - as with Putin's January 2020 visit to Syria, which Syrianpresidency marked with posts about Putin's visit to the Umayyad Mosque, the Mariamite Cathedral, meetings with their respective military officers at the Russian military headquarters in Damascus. ${ }^{5}$ Assad's February 2019 visit to Iran, to meet with Iran's Supreme Leader Ayatollah Ali Khamenei and President Hassan Rouhani, was also similarly marked by photo posts showing them together in Teheran. ${ }^{6}$ Additionally, a number of Bashar-focused posts show him speaking with foreign journalists, with captions that generally state the journalist's network or newspaper, but not their name or the subjects covered. ${ }^{7}$ While Syrianpresidency's foreign policy-focused posts hint at outside enemies, the language used is vague. By not naming any of those enemies, Syrianpresidency works to minimize their credibility or their power to challenge Assad's control of Syria - or the account's presentation of Syrian reality. These few posts echo what Joubin describes as the predominance of "strong qabaday" (a longstanding, evocative Arabic term denoting an honorable but aggressive "tough guy") in Syrian popular culture that characterized the Bashar al-Assad era until the popular uprising in 2011. Since then, Joubin sees

\footnotetext{
${ }^{4}$ Syrian Presidency (@Syrianpresidency). 2018. Six Instagram posts. 3.18.2018.

5 Syrian Presidency (@Syrianpresidency). 2020. Instagram post. Nine photos 1.7.2020.

6 Syrian Presidency (@Syrianpresidency). 2019. Instagram post. 2Three photos 2.25.2019.

7 See, for example, two 2016 interviews - with El Pais and German television channel ARD: Syrian Presidency (@Syrianpresidency). 2016. "Min muqabila al-Ra' is \#al-Assad ..." and "Min muqabila alRa' is \#al-Assad ...." Instagram posts. 2.20.2016 and 3.1.2016.
}

both pro-opposition and pro-government television screenwriters depicting "a more emotionally connected masculine ideal" through male characters portrayed as caring fathers and companionate spouses (Joubin 2016). With the exception of the 'vague enemies' posts, Bashar al-Assad's Instagram posts perform masculinity along the lines of this more recent masculine ideal, claiming it for the Syrian government, rather than for-or rather than exclusively for-members of the non-extremist Syrian opposition.

\section{Posts depicting Asma al-Assad}

Asma al-Assad has been an internationally-covered and nationally-celebrated figure since her marriage to Bashar alAssad in late 2000. She also has her own Instagram account, asmaalassad, started in September 2014, which includes many of the same photos as Syrianpresidency. However, this analysis focuses on posts about her in Syrianpresidency, analyzing how they contribute to the account's public diplomacy around the institution of the Syrian presidency, focusing on the following themes and tracing their evolution and relative prominence over the period studied: hospital visits, martyrs' family visits, school and orphanage visits, and her breast cancer diagnosis and treatment.

The posts focused on Asma al-Assad portray her as a figure of nurturing femininity, supporting the vulnerable members of the Syrian national community, including wounded soldiers and grieving families, and celebrating the achievements of students, women, and those with disabilities. Numerous posts depict her meeting with families of soldiers killed fighting revolutionary forces and ISIS militants-as in a February 2016 photograph that showed her hugging a young boy who had lost his father, as well as two uncles. ${ }^{8}$ Captions that include excerpts from her speeches tend to use spoken Syrian Arabic, and so do video clips of her meeting with wounded soldiers' families. This contrasts with excerpts and clips of Bashar al-Assad's speeches, which are generally in formal Arabic. Prior to the Syrian conflict Asma al-Assad appeared with Bashar when greeting heads of state and their spouses, or other foreign officials-most often when traveling abroad. However, she appears in the Syrianpresidency posts interacting only with other Syrians. Bashar is the one who is still shown meeting with foreign officials-mostly Iranians and Russians. These meetings are focused on military issues or political discussions, with no state dinners or spouses. Asma's exclusion from the photos of those visits suggests their working nature, but also reinforces her depictions on Syrianpresidency as focused on providing support and care for Syrians.

\footnotetext{
8 Syrian Presidency (@Syrianpresidency) 2016. “Sayyida \#Asma alAssad ma`Zayn....” Instagram post. 2.27.2016.
} 
From 2016 to 2020, the themes associated with Syrianpresidency's Asma-centered photos and posts have remained consistent, although as the intensity of the military conflict has waned, her work with wounded soldiers has shifted from visiting those recovering from battle wounds to supporting their rehabilitation and re-entry into the workforce and mainstream society. The photos of her consistently show her embracing women and children, reaching out to help a wounded soldier, sitting or kneeling with groups of children or young people, and speaking and listening thoughtfully to Syrians whether hosting them at the Presidential Palace, visiting their homes, or visiting at a hospital or rehabilitation facility. In all these roles, Syrianpresidency depicts Asma al-Assad as complementing Bashar in appearing hardworking, deeply involved in the lives of Syrian citizens, and committed to their welfare- a nurturing, caring first lady who acts as a maternal or sororal figure to support Syrians through hard times and bold achievements. In this role, her gender performance fits with normative expectations. As Pratt notes, "much women's activism [in the Middle East] has taken the form of welfare and charitable work, which has been performative of dominant gender norms of female respectability as well as class privilege (Pratt 2020). Yet her performance also reclaims this activist space for the Syrian government, against claims of civil society activism by members of the Syrian opposition.

\section{Posts depicting Bashar and Asma together}

Only seven percent of the Syrianpresidency photos in this survey depicted the Assads together in the same photographs. Over 75 percent of these were posted in 2016 and 2017 , with only two photo posts in 2018, one in 2019, and none in 2020 during the 3 months of this study. While few in number, these posts highlight themes of a closely connected couple in a companionate marriage, working for the good of Syria. They tend to depict the Assads visiting wounded soldiers in hospitals or hosting groups of citizens, like the families of wounded and martyred soldiers, or meeting with teachers on Teachers' Day. A few are "throwback" photos, including two 2016 posts showing the Assads in 2005, visiting a patient in a rural hospital and visiting an exhibition on rehabilitation and job training for wounded or disabled Syrians. (Other photos, posted outside the period under study, show them voting together or doing volunteer work.) These posts depict the Assads in the midst of others-sitting or standing side-by-side with other Syrians rather than above them or at a distance. Several also show the Assads engaged with one another: looking at one another and smiling, or walking together companionably, or at least standing close to one another while interacting with others. One, a New Year's post in 2018, shows them walking outdoors with their children-all dressed presentably but informally, in jeans, as if out for a family walk. Together, these photos suggest a marital relationship full of mutual respect and affection and suggest a modern couple working together as public servants working for Syria and Syrian citizens.

\section{Analysis}

The posts on Syrianpresidency from 2016 to 2020 lend themselves to three related strands of analysis, which collectively help explain the work that this account does in service of the Assad government's digital public diplomacy. As noted above, it argues that the account operates at three levels. First, it works to harness citizen acquiescence through an updated version of what Lisa Wedeen termed 'acting as-if' politics. Second, it attempts to efface opposition to the Assad government and expunge government violence from global consciousness through a politics of erasure. Third, it builds on the first two by trying to persuade regional and international audiences of the Assads' respectability via gendered displays of Euro-normative modernity. Collectively, these efforts illustrate one of Manor's arguments: that digital public diplomacy extends the reach of nation branding, or in this case perhaps leader-and-nation branding, initiatives (Manor 2019).

\section{Acting 'As-If'}

In one of the most influential analyses of Hafez al-Assad's presidency, political scientist Lisa Wedeen argued that the cult of personality constructed around him did not require Syrians to actually revere him as a father leader, or to believe the often visibly-inflated claims made about him. They simply needed to act $a$ s if they did, which disciplined Syrian citizens into what Wedeen described as a "politics of public dissimulation" (Wedeen 1999) organized around symbols and images that saturated public space but had little connection to citizens' lived experience with the Assad government. The result was a political atmosphere that produced obedient citizens whose actions as if made them complicit with the regime, and kept them isolated from one another out of fear that others might be acting out of belief.

With Bashar al-Assad, the politics of acting as if have been updated to fit the current context, and so have the relevant symbols and images. While large paintings and murals of both Assads remain part of the Syrian public landscape, and smaller photos of them, and especially Bashar al-Assad, are prominently displayed inside public buildings, the Assad government's visual imagery has shifted in focus and reach. Two examples help illustrate this point. First, as Syrianpresidency demonstrates, Bashar al-Assad is depicted spatially as both part of the body of Syrian citizens and as its leader: standing with groups of Syrians and standing or sitting 
authoritatively by himself or in front of and above them. The proliferation of images on social media platforms enables a wider range of depictions of al-Assad than was possible with photos and paintings in public spaces, which depicted each Assad individually or together as father and son. Second, the expansion of images to include Asma al-Assad was a major departure from Hafez al-Assad's era. Hafez' wife Anisa Makhlouf, while recognized as an important influence on him, only rarely appeared in public, and images promoting the Assad cult of personality did not include her. Asma al-Assad's prominence in Syrianpresidency is central to its claims that the Assads are respectable participants of a Euro-normative, global modernity-the gendered aspects of which are discussed in more detail below. Together, these shifts in focus and reach ask viewers of Syrianpresidency's posts to behave as if the images depict the full story: as if displays of modernity obviate the realities of autocratic governance, and as if the Syrian conflict involves only a vague, shadowy Other instead of Syrian citizen opposition. Through this as-if politics, Syrianpresidency supports Assad government efforts at domestic diplomacy, aimed at disciplining Syrian citizens into practices of obedience. ${ }^{9}$

\section{Politics of erasure}

This second as-if engagement connects to the Assad government's broader diplomatic approach to the conflict: effacing central aspects of it through a politics of erasure. In colonial contexts, this practice works to "erase" the presence of Indigenous and Black communities, and to similarly erase their histories in order to "disremember" anything that might counter colonial narratives of civilizational and racial hierarchy (Na'puti 2019; Rwafa 2014). In the Syrian case, the violence of erasure silences and negates both a resistant set of lived experiences and an ugly reality of state violence. Syrianpresidency works, through images that depict Asma al-Assad supporting wounded soldiers through physical rehabilitation and Bashar al-Assad being embraced by conservatively dressed Syrian women 'liberated' from territories previously under 'terrorist' control, to silence Syrian opposition and efface the Assad government's regular use of violence.

This is not a politics of denial: the account does not post images or texts that focus on denying or refuting accounts of the realities of the Syria conflict. It simply erases them, actively un-representing Syrian citizens opposed to the Assad regime, Syrians living as internally displaced persons or refugees, torture committed by Syrian state forces, bombing campaigns against civilians, and similar. In this way, it

\footnotetext{
${ }^{9}$ For a brief analysis of the Syrian Arab News Agency's role in Bashar al-Assad's as-if politics, see Fielding-Smith (2015).
}

echoes Tuchman's arguments about how United States mass media historically have 'symbolically annihilated' women by portraying them either in stereotypically gender-typed roles or by un-representing them-by not portraying them at all (Tuchman 1978/2000). Like other applications of Tuchman's argument, this focuses less on the constrained portrayals and more on the annihilating effects that Syrianpresidency's un-representation has. It is not possible to analyze how it portrays Syrians opposed to the Assad government, for example, because the account does not acknowledge them. It is not possible to analyze how it portrays the Assad government's violence against civilians, because the account does not acknowledge state violence. In short, these acts of annihilation and erasure are not incidental but essential to the digital diplomacy work of the Syrianpresidency Instagram account and the Assad government's other social media platforms.

\section{Gendered modernity}

As noted above, these posts also evince what scholars of colonial history in the Middle East and other regions describe as a bid to demonstrate gendered displays of Euro-normative modernity. It echoes colonial-era efforts to 'measure' and evaluate colonized societies based on their relative conformance to particular European gender relations and gendered activity norms. These pressures sparked lively internal debates among men and women in colonized societies, connecting with existing conceptions of gendered relations and indigenous traditions of social reform. In the Middle East, these frequently generated reconfigured notions of gendered modernity, with distinct and complementary roles for men and for women (Abu-Lughod 1998; ClancySmith and Gouda 1998). They also increasingly emphasized the merits of companionate marriage: one in which husband and wife developed a lasting affection, based on intellectual, moral, and patriotic sensibilities, and served as anchors of the nuclear family that they established (Motlagh 2012).

Syrianpresidency's posts evince multiple visual instantiations of these gendered displays of modernity-or performances of Euro-normative gender within a Syrian context. It depicts Bashar al-Assad displaying empathetic and caring forms of masculinity, particularly in his interactions with Syrian women and children-but also in his interactions with ordinary Syrian men and with Syrian soldiers. It depicts Asma al-Assad as visibly present in the public sphere, yet focused primarily on citizen welfare: encouraging Syrian schoolchildren in their academic pursuits, comforting grieving families mourning a father, husband, or son lost to battle, and supporting wounded soldiers in their physical and work rehabilitation. Their complementary but distinct activities include the groups with which they most frequently interact: Asma al-Assad's regular interactions with women and 
children (and with grieving or wounded men); Bashar's interactions with men (and with grieving or otherwise distressed women and children). Their primary geographic locations function similarly: while both frequently appear outside the Presidential Palace, Asma is more frequently depicted in schools and private homes, while Bashar is more frequently depicted in Parliament or other public institutions (houses of worship, military encampments.). Finally, while the Arabic-language captions typically use formal Arabic, direct quotes from Asma are more likely to appear in spoken Syrian Arabic, while those from Bashar al-Assad are more likely to appear in standard Arabic - the former a more conversational register, associated with everyday interactions, and the latter a more formal register, associated with official or formal contexts (Eid 2007).

Collectively, these visual and textual cues guide viewers to see the Assads' roles as distinct. In these posts, the Assads perform modern roles that remain gendered in particular ways: sober, caring masculinity and nurturing, supportive femininity. In doing so, they make a claim to regional and international audiences about the modernity, and hence respectability, of the Assads. The same is true of the images that depict the two of them together. While few in number, they visually reinforce Syrianpresidency's depiction of the Assads as an affectionate, companionate marital couple, working in complementary ways to fulfill the roles of President and First Lady of Syria. That these posts include images of them voting, as if Syrian elections were competitive, further extends the account's visual claim to international respectability.

\section{Conclusions}

Syrianpresidency offers a case study of sustained digital public diplomacy efforts, maintained with consistent focus and energy over multiple years. It raises interesting questions about digital diplomacy and its blurring of traditional demarcations between foreign and domestic audiences-a blurring exacerbated by Syria's ongoing civil conflict. The account's multiple audiences reflect what Huijgh calls the "amalgamation of domestic and international publics, actors, and policy spheres", as well as the "permeability" between the categories of foreign and domestic (Huijgh 2013). These aspects are intensified in Syria's civil war context, given the massive internal displacements and informal and formal refugee communities of Syrians around the region, Europe, and further abroad - and given the range of regional and international actors, whether state, NGO, or other non-state organizations involved in the conflict as direct or indirect supporters of one or more sides. As a result, digital public diplomacy, with its capacity to engage domestic and foreign audiences together, has gained in importance.

In conjunction with the Assad government's other social media accounts, Syrianpresidency has played a crucial role in promoting Bashar and Asma al-Assad as complementarily gendered public servants leading a modern Syria. Collectively, Syrianpresidency's posts focus on Syria's military, patriotic and self-sacrificing citizenry, talented young people, good governance, history of succeeding despite external and internal challenges, and religious diversity as foundational elements of the Syrian nation state. For the account's target audience, the number of likes and positive comments suggest that these messages successfully counter the depiction of the Assads in opposition and most international media, despite the evidence that counters the Assads' self-portrayals. Syrianpresidency's reception on Instagram offers a sobering addendum to Manor's assertion that digital technologies have such impact on public diplomacy because so much of society has become digitalized (Manor 2019).

Genderedness is critical in these efforts and deeply embedded in these posts. Syrianpresidency frames the Assads for a regional and international audience through the lens of gendered modernity, portraying them as companionate spouses serving Syrians in complementary roles. Syrianpresidency aims its public diplomacy at domestic and foreign audiences, working to project a positive image as part of its efforts to manage and ultimately end the Syria conflict. In doing so, it is supported by efforts that engage in an updated form of as-if politics around the cult of the leader in Syria, and a politics of erasure or symbolic annihilation that works to efface the regime's violence and citizen resistance through silence. On Instagram, it is further supported by two key social approval indicators: its total number of followers and the number of likes on every post. Managing or limiting these latter responses may curtail the account's effectiveness as a public diplomacy tool.

\section{References}

Abu-Lughod, Lila, ed. 1998. Remaking Women: Feminism and Modernity in the Middle East. Princeton University Press: Princeton.

al-Haj Saleh, Yassin. 2017. Impossible Revolution: Making Sense of the Syrian Tragedy. Oxford: Oxford University Press.

Boy, John, and Justus Uitermark. 2016. How to Study the City on Instagram. PLoS ONE 11 (6): e0158161.

Butler, Judith. 1999. Gender Trouble: Feminism and the Subversion of Identity. New York: Routledge.

Caldeira, Sofia. 2016. Identities in Flux: An Analysis to Photographic Self-Representation on Instagram. Observatorio 10 (3): 135-158.

Clancy-Smith, Julia, and Frances Gouda, eds. 1998. Domesticating the Empire: Race, Gender, and Family Life in French and Dutch Colonialism. Charlottesville: University Press of Virginia. 
Duncombe, Constance. 2019. Digital Diplomacy: Emotion and Identity in the Public Realm. The Hague Journal of Diplomacy 14 (1-2): 102-116.

Eid, Mushira. 2007. Arabic on the Media: Hybridity and Styles. In Approaches to Arab Linguistics: Presented to Kees Versteggh on the Occasion of His Sixtieth Birthday, 403-434. Leiden: Brill.

Fielding-Smith, Abigail. 2015. "Assad's 'As If'”. In The New Authoritarians: Ruling Through Disinformation, 26-31. London: Legatum Institute.

Holiday, Steven, Matthew J. Lewis, and Jack L. LaBaugh. 2015. Are You Talking To Me? The Socio-political Visual Rhetoric of the Syrian Presidency's Instagram Account. Southwestern Mass Communication Journal 30 (2): 1-27.

Huijgh, Ellen. 2013. Changing Tunes for Public Diplomacy: Exploring the Domestic Dimension. Exchange: the Journal of Public Diplomacy 2 (1): 62-73.

Joubin, Rebecca. 2016. The Politics of the Qabaday (Tough Man) and the Changing Father Figure in Syrian Television Drama. Journal of Middle East Women's Studies 12 (1): 50-67.

Khatib, Line. 2011. Islamic Revivalismm in Syria: The Rise and Fall of Ba thist Secularism. Oxford: Routledge.

Kozak, Christopher. 2015. An Army in All Corners: Assad's Campaign Strategy in Syria. Institute for the Study of War, April 2015. https://www.jstor.org/stable/pdf/resrep07883.pdf.

Leaver, Tama, Tim Highfield, and Crystal Abidin. 2020. Instagram. Cambridge, UK: Polity Press.

Lee, Eunji, Jung-Ah. Lee, Jang Ho Moon, and Yongjun Sung. 2015. Pictures Speak Louder than Words: Motivations for Using Instagram. Cyberpsychology, Behavior, and Social Networking 18 (9): 552-556.

Manor, Ilan. 2019. The Digitalization of Public Diplomacy. Cham: Palgrave Macmillan.

Motlagh, Amy. 2012. Burying the Beloved: Marriage, Realism, and Reform in Modern Iran. Stanford: Stanford University Press.

Na'puti, Tiara. 2019. Speaking of Indigeneity: Navigating Genealogies Against Erasure and \#RhetoricSoWhite. Quarterly Journal of Speech 105 (4): 495-501.

Neumann, Iver. 2020. The Evolution of Visual Diplomacy. In Diplomatic Tenses: A Social Evolutionary Perspective on Diplomacy, 46-71. Manchester: Manchester University Press.
No Author. New law abolishes honor killings' mitigating excuse in Syria", Enab Baladi 3.14.2020, https://english.enabbaladi. net/archives/2020/03/new-law-abolishes-honor-killings-mitig ating-excuse-in-syria/.

Pisarska, Katarzyna. 2016. The Domestic Dimension of Public Diplomacy: Evaluating Success Through Civil Engagement. London: Palgrave Macmillan.

Pratt, Nicola. 2020. Embodying Geopolitics: Generations of Women's Activism in Egypt, Jordan, and Lebanon. Oakland: University of California Press.

Rafizadeh, Majid. 2012. Assad's Future and Syria's Opposition Groups. Yale Journal of International Affairs 113: 113-114.

Rwafa, Urther. 2014. Playing the Politics of Erasure: (Post) Colonial Film Images and Cultural Genocide in Zimbabwe. Journal of Literary Studies 30 (2): 104-114.

Smith, Lauren Reichart, and Jimmy Sanderson. 2015. I'm Going to Instagram It! An Analysis of Athlete Self-Presentation on Instagram. Journal of Broadcasting and Electronic Media 59 (2): 342-358.

Tuchman, Gaye. 2000. The Symbolic Annihilation of Women by the Mass Media, reprinted in Culture and Politics: A Reader, ed. Lane Crothers and Charles Lockhart. New York: St Martin's Press.

van Dam, Nikolaos. 2011. The Struggle for Power in Syria: Politics and Society Under Asad and the Ba th Party. London: IB Tauris.

Wedeen, Lisa. 1999. Ambiguities of Domination: Politics, Rhetoric, and Symbols in Contemporary Syria. Chicago: University of Chicago Press.

Publisher's Note Springer Nature remains neutral with regard to jurisdictional claims in published maps and institutional affiliations.

Andrea Stanton is Associate Professor of Islamic Studies and Interim Director of the Center for Middle East Studies at the University of Denver (Colorado, USA). 